\title{
Tradition and belief in Kegelisahan Madu
}

\author{
Hiqma Nur Agustina* \\ English Department, State Polytechnic of Malang, Malang, Indonesia
}

\begin{abstract}
For someone who has studied Islam at a pesantren, the point of view about polygamy is reasonable and permissible. Kegelisahan Madu is interesting to study because it tells the author's perspective of a woman. Polygamy often creates an endless contradiction to be discussed and debated. Polygamy can see as a solution or problem depending on the perpetrators. As a result of this study, the author clearly shows her partiality towards women who experienced polygamy or her disapproval of polygamy practices.
\end{abstract}

Keywords: culture; pesantren society; polygamy; sociology of Literature, tradition

\section{Introduction}

The sociological approach has methodological implications in the form of a fundamental understanding of human life in society [1]. Literature is a reflection of society, through literary works, an author expresses the problems of life that the author himself participates in facing it. Literary works receive influence from the community and, at the same time, be able to influence the community.

Sociology of Literature studies the nature of the relationship among members of the literary community and knows the causes of the productive relationship with all its effects [2]. The community often determines the value of literary works that lived in an era, while writers themselves are members of the community who are bound by certain social statuses and cannot avoid the influence that they receive from the environment that raises and shapes them.

There are two main trends in the study of literary sociology, which include an approach based on the assumption that Literature is a small mirror of socio-economic processes and an approach that prioritizes literary texts as a study material which then looks for social aspects of literary works.

\footnotetext{
* Corresponding author: hiqma@polinema.ac.id
} 
Sociology of Literature is research focused on human problems because Literature often reveals the struggle of humanity in determining its future, based on imagination, feelings, and intuition (2003: 79) [3].

The literature presents a picture of life, and life itself is a social reality [4]. In this meaning, life encompasses relationships between people, between people and people, between people, and between events that occur within a person. However, events that occur in a person's mind, which are often the material of Literature, are reflections of one's relationship with others or with society, foster individual social attitudes, or even trigger certain social events.

Kegelisahan Madu is a social critique of the polygamy's practice done by Islamic leaders, especially those who become Kiai or pesantren leaders. Evi Rahmawati wrote this text, a student at the State Islamic University of Jakarta and head of the Formaci study forum (Ciputat Student Forum), and contained in a collection of short stories Jurnal Perempuan entitled Menulis Tubuh. [5] The problem of this research is that polygamy's practice in the pesantren community often causes a contradiction from the community.

The narrative in uncovering polygamy in the text Kegelisahan Madu is not riveting, but this narrative has a specialty in the simple plot and character but can criticize polygamy very profoundly. It is the advantage of this short story. The author's views and impartiality of the practice of polygamy among pesantren want to criticize-Furthermore, an assessment of the sustainability of the practice of polygamy left in the community.

Research on women who became the victims of polygamy in Afghanistan has resulted in them being victims of violence, both physically and verbally [6]. Likewise, women in Saudi Arabia must accept without being able to reject the decisions of their husbands [7]. The two countries where the research conducted the majority also adopted Islam as in Indonesia.

Literature is not a fact of social life, but it always based on social reality. Literature is a social reality that experiences the author's processing [8]. A typical short story's strength is its ability to raise issues more - meaning implicitly - than just what is told. Short single plot stories generally consist of only one sequence of events that followed until the story ends (not finished because many short stories do not display a clear solution. Not infrequently, the completion left to the reader 's interpretation). It happens in the text Kegelisahan Madu.

The author of fiction is an actor as well as an observer of various problems of life who try to uncover and elevate them into work. As a work of fiction, this text succeeded in bringing up issues that have led to the emergence of supporters and opponents of polygamy in Indonesian society. No wonder because, as a vast country with a majority Muslim population, the discussion about marriage with more than one wife often triggers a controversy.

This research uses a sociological approach. The sociological approach is the existence of an intrinsic relationship between literary works with the community. The relationship sees the author uses the issues that are developing in the community. The sociological approach also has methodological implications in the form of a fundamental understanding of human life in society. Through her intersubjectivity, the author explores the wealth of the community and puts it into literary works, which are then enjoyed by the reader.

A patriarchal cultural construction represses all orders of values, rules, and norms. Consequently, the construction also legitimizes gender constructions and rules that tend to disadvantage women [9]. The practice of polygamy is very close to patriarchy, which then often represses women. The status and role of women in Muslim societies have a function related to multiple factors that are hardly religious-oriented so that when patriarchal construction and gender relations are openly in the name of religion, contradictions are very contrary to what is written in the Koran [10]. 


\section{Social criticism of the polygamy's practice}

A pesantren environment is a place where students learn religious knowledge from both the yellow book and the holy Quran. The students live and grow in an environment that upholds the values of Islam. One of them is that they learn about the terms and laws of marriage, according to Islam taught by the Prophet Muhammad.

The main character in this short story is a woman who uses the perspective of "I." She is a wife of a Kiai in a pesantren. Her husband's character always indoctrinates to be obedient wife, always be grateful for God's grace, share with others, follow his command without questioning why she should follow, kiss their hand, wash his clothes, bathe him, warm him, fulfill all his needs. [5] page 208.

The doctrine of the religious experts towards his wife is often in the name religion so that they are as if the husband is right, and all his commands do not violate the rules of religion in the following quote.

Suamiku selalu menekankan bahwa istri salehah adalah yang paling bahagia di dunia dan akhirat, dan aku akan menjadi istri salehah jika aku selalu berbuat baik pada suamiku. Belakangan, aku mulai berpikir bahwa berbuat baik adalah berarti menjalankan perintah. Menuruti kehendaknya jika ingin dilayani, bahkan Ketika ia tak meminta untuk dilayani, karena hal itu sudah diklaim sebagai rutinitas yang harus sudah "kusadari."

My husband always emphasizes that a pious wife is the happiest in the world and the hereafter, and I will be a good wife if I always do good to my husband. Later, I began to think that doing good was to follow orders. Obeying his will if he wants to serve, even when he does not ask to serve because it claimed as a routine that I must have "realized."

The author's reading of this text refers to the polygamy that the Kiai character wants to do. This Kiai character wants to marry the youngest girlfriend of his younger brother's friend on the grounds of wanting to help the girl from the evil forces of the big city demons. Moreover, the Kiai character had previously been married twice. Each has two sons from his wife.

The Kiai character depicted always uses religious doctrine in his household to negate other understandings of polygamy. As in the following quote, a wife who does not allow her husband to remarry is considered a dissident.

Istri pertamanya adalah pembangkang, begitulah setidaknya yang ia katakan kepadaku.

Istrinya itu tidak bersedia menerima kehadiran wanita lain dalam kehidupan rumah tangganya. Akhirnya, ia bersikeras meminta cerai. Suamiku selalu menekanku untuk mengambil pelajaran dari istri pertamanya itu. Menurutnya, istri pertamanya itu tidak akan pernah bahagia di akhirat karena ia bukan wanita salehah [5 [ page 211.

His first wife was a dissident, so at least he told me. His wife was not willing to accept the presence of other women in her domestic life. Finally, he insisted on asking for a divorce. My husband always presses me to take lessons from his first wife. According to him, his first wife would never be happy in the afterlife because she was not a pious woman [5 [page 211.

The concept of obedience criticized by the authors intended to build an awareness that women are not merely objects in a marriage. A submissive wife turns out to be disrespected by her husband; instead, she looks for other objects that become her equal for her satisfaction. One interesting thing from the author's idea is that the emphasis on the concept of the piety 
of women from the Kiai figures originating from the pesantren environment turns out to be different from the understanding of the female characters in the story. The "I" character thinks the Kiai believes the religion is very different from the religion she believes in the following quote.

Agama yang selalu ditekankan aturan-aturannya oleh suamiku terhadapku tentang semua konsep kesalehan seorang wanita, rasa-rasanya tidak memberiku apa-apa selain kepatuhan yang hampa. Kepatuhan yang mengaburkan arti agama itu sendiri dalam hidupku [5] page 312.

Religion, which my husband always emphasized on his rules about me about all the concepts of godliness of a woman, felt it gave me nothing but empty obedience. Obedience obscures the meaning of religion itself in my life [5], page 312.

The piety and environment of the pesantren undeniably contributed to the pattern of thinking of a santri. However, it should remember that polygamy practices are sometimes not in line with the polygamy practices carried out by the Prophet Muhammad. The Prophet Muhammad saw got direct orders from Allah for several reasons, which were accepted by many Muslim women. However, the practice of polygamy practiced by men in the current era is not in line with him.

The woman author confronts the practice of polygamy from the main character with her husband by displaying a resistance, namely by displaying the ending of the affair of the female tempter with her husband's younger brother. The female temptress showed perfection, and piety did not have good morals. Another message is that a male graduate from pesantren must be able to consider the best decisions in marriage by examining the good and bad sides, although not all-male graduates from pesantren choose the same path, namely in deciding to do polygamy.

Baju terakhir yang belum sempat kumasukkan koper adalah baju yang dipinjam gadis itu seminggu yang lalu, saat ia datang untuk kedua kalinya mengusik kehidupan kami. Baju itu ada di kamar adik iparku, tempat di mana setahun lalu aku pernah tanpa sengaja melihat gadis itu dan adik iparku telanjang di atas ranjang kesayangan mertuaku [5] page 212. Topik kesalehan seorang perempuan yang dikritis oleh pengarang ditampilkan bukan dari penampilan fisik semata, namun juga dari pemahamannya akan perbuatan dosa, halal dan haram.

The last shirt I hadn't had the chance to put in the suitcase was the one the girl had borrowed a week ago when she came the second time to disturb our lives. The clothes are in my brother-in-law's room, a place where a year ago I had accidentally seen the girl and my brother-in-law naked on my father-in-law's favorite bed. The topic of revealed piety is not only from the physical appearance but also from the understanding of sin, halal, and haram.

The author criticizes the traditional values and beliefs of the Kiai character to practice polygamy. It is because pesantren graduates should understand more about the law of marriage by imitating the Prophet Muhammad by not hurting compliant wives and serving their husbands. 


\section{Conclusion}

Kegelisahan Madu is fascinating because it portrays the values held by students of Islamic boarding school graduates for polygamy marriages. The author shows her impartiality in the practice of polygamy in Indonesian society. This study also shows the piety of a wife not only seen from her obedience to her husband but also made the reader aware that the piety of a wife is from obedience to religious values that bring peace and happiness to all God's creatures.

\section{References}

1. N. Kutha Ratna. Teori, Metode, dan Teknik Penelitian Sastra. Pustaka Pelajar. Yogyakarta (2004)

2. J. Soemarjo. Masyarakat dan Sastra Indonesia. Nur Cahaya. Yogyakarta (1983)

3. S. Endraswara. Metodologi Penelitian Sastra. Pustaka Widyatama. Yogyakarta (2003)

4. S. Djoko Damono. Sosiologi Sastra. Semarang: Magister Ilmu Susastra Undip. (2003)

5. E. Rahmawati. Kegelisahan Madu dalam Kumpulan Cerpen Jurnal Perempuan Menulis Tubuh. Editor Gadis Arivia. Jurnal Perempuan. Jakarta Selatan (2012)

6. H. Nur Agustina. Afghan Women's Repression by Patriarchy in My Forbidden Face by Latifa, in Proceeding of The Asia-Pacific Forum for Research in Social Sciences and Humanities, APRISH, 7-9 November 2016, Depok, Indonesia (2016)

7. H. Nur Agustina. Perjuangan Perempuan Saudi Arabia dalam Novel Misteri Mencari Nouf Karya Zoe Feraris, in Proceeding of the International Conference on Feminism: Intersecting Indentities, Yayasan Jurnal Perempuan, 23 - 24 September 2016, Jakarta, Indonesia (2016)

8. B. Nurgiyantoro Teori Pengkajian Fiksi. Gadjah Mada University Press. Yogyakarta (2005)

9. H. Nur Agustina. Represi dan Resistensi Perempuan dalam Dua Karya Diaspora Afghanistan A Thousand Spendid Suns and My Forbidden Face. Dissertation. Universitas Indonesia. Depok (2019)

10. A. Barlas. Believing in Women in Islam. Unreading Patriarchal Interpretations of the Qur'an. University of Texas Press. USA (2002) 